Easterfield Medal of the New Zealand Section, Royal Institute of Chemistry

THE New Zealand Section of the Royal Institute of Chemistry has instituted a new silver medal, to be known as the Easterfield Medal, in honour of the late Sir Thomas Easterfield, the first professor of chemistry in Victoria University College, Wellington, and later the first director of the Cawthron Institute. The Medal will be awarded every two years to a New Zealand chemist less than thirty-five years of age who has carried out research work of outstanding quality and originality, the major portion of it being done in New Zealand. The first award will be made this year, and further details can be obtained from the honorary secretary, New Zealand Section, Royal Institute of Chemistry, P.O. Box 250, Wellingtion, C.1.

\section{Royal Institution: Officers}

AT the annual meeting of the members of the Royal Institution, held on May 1, the following officers were elected: President, Lord Brabaizon of Tara; Treasurer, Dr. L. H. Lampitt ; Secretary, Mr. S. Robson; Managers, Mr. E. R. Davies, Sir Walter Drummond, Sir Alfred Egerton, Mr. H. S. Gibson, Mr. A. C. Hartley, Mrs. H. K. Hawkes, Prof. A. V. Hill, Mr. L. B. W. Jolley, Dr. H. Lowery, Mr. A. J. Philpot, Mr. W. E. Schall, Mr. P. H. Schwarzschild, Sir George Thomson and Mr. Frank Wakeham; Visitors, Mr. W. W. Abson, Mr. F. G. Brown, Dr. H. K. Cameron, Mr. A. D. R. Caroe, Mr. A. H. Ewen, Prof. James Greig, Wing Commander G. e. Hughes, Dr. G. M. Lees, Prof. Kathleen Lonsdale, Mr. Arthur Marshall, Mr. M. M. Melinsky, the Hon. Philip Samuel, Dr. P. C. Spensley, Mr. W. R. Stevens and Dr. Norman Stuart.

\section{Royal Photographic Society Exhibition of Under- water Photography}

AN exhibition of photographs taken under water has been arranged by the Royal Photographic Society and will be on show in its house at 16 Princes Gate, London, S.W.7, until May 29 (Sundays excepted), admission free. It comprises about a hundred photographs, in monochrome and colour, of subjects by Commandant Jacques-Yves Cousteau, Henri Broussard, Dimitri Ribikoff, and Robot-Berning and Co., and members of the Under-water Explorers Club. Other items include photographs from Marconi's Wireless Telegraph Co., Ltd., and Siebe Gorman and Co., Ltd., taken off the monitor screen during underwater television operations. The Royal Naval Scientific Service has contributed a special section of fifty prints, showing propeller studies, wreck surveys and experimental techniques.

\section{Earthquakes during February}

There were some twenty-six strong earthquakes during February, twelve of which had instrumental magnitude 6 and greater. The greatest two had instrumental magnitude 71 and occurred on February 1 near the Volcano Islands (lat. $24 \frac{1}{2}^{\circ} \mathrm{N}$., long. $142 \frac{1}{2}^{\circ} \mathrm{E}$.) and on February 11 in Ningsia Province, China (lat. $39 \frac{1}{2}^{\circ} \mathrm{N}$., long. $101^{\circ} \mathrm{E}$.), respectively. The shock which did most damage during the month had instrumental magnitude $6 \frac{1}{4}$ and an epicentre near lat. $17 \frac{1}{2}^{\circ} \mathrm{N}$., $92 \frac{1}{2}^{\circ}$ W., causing extensive property damage at Chiapas in Mexico. Two earthquakes occurred at a focal depth of $600 \mathrm{~km}$., the first being on February 14 near the Fiji Islands, and the second on February 20 in the Flores Sea. Reports were received from the
United States Coast and Geodetic Survey in cooperation with Science Service and the Jesuit Seismological Association, Durham, 'Lwiro (Belgian Congo), Pasadena, Strasbourg, Toledo and Uccle.

\section{Announcements}

WE regret to announce the death on April 25 of Lady Mary Lilian Boyd Dawkins, widow of Sir William Boyd Dawkins, aged ninety.

THE Council of the Royal Society of Edinburgh has awarded the Keith Prize for the period 1951-53 to Dr. D. E. Rutherford, Department of Mathematics, University of St. Andrews, for his paper, "Some Continuant Determinants arising in Physics and Chemistry", and other publications in the Proceedings of the Society.

THE first Dickinson Memorial Lecture of the Newcomen Society will be delivered by Prof. Charles Singer in the Science Museum, London, S.W.7, on May 12 at 6 p.m. The Lecture is to be a biennial one.

At the annual meeting of the Zoological Society of London on April 29, Sir Landsborough Thomson was elected president in succession to Lord Alanbrooke. Dr. T. C. S. Morrison-Scott was elected treasurer, and Lord Chaplin secretary. New members of Council are Captain K. Caldwell, Mr. A. Ezra, Lord Forester, Dr. H. W. Parker, Mr. Peter Scott and Mr. S. Wilson Kitchen.

Mr. J. E. Cummins, chief scientific liaison officer, Australian Scientific Liaison Office, London, is returning to Australia after six years in London. He will be succeeded by Mr. Walter Ives, who is at present secretary (agricultural and biological sciences) of the Commonwealth Scientific and Industrial Research Organization, Melbourne.

The Minister of Transport, the Right Hon. Alan Lennox Boyd, will open the new research laboratory and proving ground of the Motor Industry Research Association at Lindley, near Nuneaton, Warwickshire, on May 21.

AN exhibition on "Dry Rot and Woodworm" will be opened at the Royal Sanitary Institute (90 Buckingham Palace Road, London, S.W.1) on May 12 by the Right Hon. Sir David Eccles, Minister of Works. The Exhibition is being presented in collaboration with the Department of Scientific and Industrial Research and the Central Office of Information, and will remain open until July 17.

THE British Society of Rheology is holding a conference on "Rheology in Mechanical Engineering" in the Mechanical Engineering Research Laboratories, East Kilbride, near Glasgow, during June 10-12. The conference will be free and open to anyone interested in this field. Application forms, to be returned before May 15, can be obtained from Dr. D. P. Feltham, Flat H.12, Sloane Avenue Mansions, London, S.W.3.

THE Committee on Vacuum Techniques is holding a symposium during June 16-18 at the BerkeleyCarteret Hotel, Asbury Park, New Jersey. About twenty-five papers will be read, discussing nomenclature and standards; new equipment and instruments ; fundamental developments in vacuum technology ; methods and techniques ; applications; and processes. Persons and organizations interested in attending the symposium should write to the Committes on Vacuum Techniques, Box 1282, Boston 9, Mass. 